\title{
Weed Control in Winter Wheat (Triticum aestivum L.) with Preplant Applications of Glyphosate plus Mesotrione or Saflufenacil
}

\author{
Nader Soltani*, Lynette R. Brown, Christy Shropshire, Peter H. Sikkema \\ University of Guelph Ridgetown Campus, Ridgetown, Canada \\ Email: soltanin@uoguelph.ca
}

Received 13 May 2015; accepted 27 June 2015; published 30 June 2015

Copyright (C) 2015 by authors and Scientific Research Publishing Inc.

This work is licensed under the Creative Commons Attribution International License (CC BY). http://creativecommons.org/licenses/by/4.0/

(c) (i) Open Access

\begin{abstract}
There is limited information on weed control with glyphosate plus mesotrione or saflufenacil when applied prior to seeding winter wheat in the autumn. A total of 12 field trials (six for each herbicide tankmix) were conducted over a three-year (2010-2012) at two locations (Ridgetown and Exeter, Ontario) to evaluate the effect of glyphosate plus mesotrione or saflufenacil at various rates for broadleaf weed control and red clover establishment in winter wheat. Glyphosate (900 $\mathrm{g}$ ae ha-1) and tankmixes of glyphosate $\left(900 \mathrm{~g} \mathrm{ae} \mathrm{ha}^{-1}\right)$ plus mesotrione or saflufenacil at $12.5,25,50$, $75,100,150$ and $200 \mathrm{~g}$ ai $\mathrm{ha}^{-1}$ applied preplant (PP) in the autumn resulted in minimal visible injury (0\% - 2\%) in the autumn and on May 1 and June 1 of the following spring in winter wheat. The PP application of glyphosate alone or in combination with mesotrione or saflufenacil provided only $1 \%-30 \%$ control of common ragweed in the following spring. The PP application of glyphosate in combination with mesotrione or saflufenacil provided $74 \%-100 \%$ control of wild mustard at 2 and 4 weeks after emergence (WAE) in autumn but the control was only $0 \%-35 \%$ on June 1 of the following spring. Glyphosate plus mesotrione or saflufenacil did not have any effect on seed moisture content and yield of winter wheat compared to glyphosate alone. Clover establishment was reduced with glyphosate plus mesotrione at the two highest rates but was not affected with glyphosate plus saflufenacil compared to glyphosate alone. Based on these results, glyphosate alone and in combination with mesotrione or saflufenacil applied PP in the autumn at rates evaluated did not provide adequate residual control of common ragweed, common lambsquarters and wild mustard in the spring of the following year in winter wheat.
\end{abstract}

\section{Keywords}

Cereals, Injury, Height, Herbicide, Tolerance, Yield

\footnotetext{
${ }^{*}$ Corresponding author.
} 


\section{Introduction}

Canada is the 7th largest wheat (Triticum aestivum L.) producer in the world producing nearly 25,000,000 MT of wheat annually from which approximately 17,000,000 MT valued at $\$ 5.4$ billion is exported to other countries [1]. Growers in Ontario like to include winter wheat in the rotation with other crops such as soybean and corn to help maintain soil structure and break pest cycles including weeds. Herbicides registered for use in winter wheat have not changed significantly in the past 20 years in Ontario [2]. More research is needed to evaluate the efficacy of recently developed herbicides with a novel mode of action in winter wheat.

Mesotrione is a triketone herbicide that provides control of annual broadleaved weed species such as velvetleaf (Abutilon theophrasti Medic.), redroot pigweed (Amaranthus retroflexus L.), common lambsquarters (Chenopodium album L.), common cocklebur (Xanthium strumarium L.), ladysthumb (Polygonum persicaria L.) and giant ragweed (Ambrosia trifida L.). Mesotrione can also control annual grass weeds such as barnyardgrass (Echinochloa crus-galli (L.) Beauv.) and large crabgrass (Digitaria sanguinalis (L.) Scop.) [2] [3]. Mesotrione inhibits the p-hydroxyphenylpyruvate dioxygenase (HPPD) enzyme which catalyzes the conversion of tyrosine to plastoquinone and $\alpha$-tycopherol within plants [3]. Mesotrione can be applied preplant (PP), PRE (preemergence) or POST (postemergence) to a number of crops including corn, asparagus, cranberry and sod [1]. Mesotrione is absorbed by the germinating seed, emerging root and shoot and is distributed throughout plants by translocation in the xylem and phloem [3]. Mesotrione injury symptoms in susceptible plants include bleaching of meristemic tissue followed by growth cessation and necrosis within 3 - 5 days [2] [3].

Saflufenacil is a pyriminedione herbicide that controls annual broadleaved weeds including redroot pigweed, velvetleaf, common lambsquarters, common cocklebur, common waterhemp (Amaranthus rudis L.), ladysthumb, common ragweed (Ambrosia artemisiifolia L.) and giant ragweed [3]-[5]. Saflufenacil inhibits protoporphyrinogen-IX-oxidase (PPO). Saflufenacil can be applied PP and PRE to barley, wheat, corn and soybean [2]-[5]. Saflufenacil has both contact and residual activity against susceptible weeds, and is mainly translocated in the xylem and has limited mobility in the phloem [5] [6]. Susceptible plants show injury symptoms which include leaf chlorosis followed by necrosis and complete death within 1 to 3 days [5] [6].

Glyphosate is an organophosphorus non-selective herbicide that controls a broad-spectrum of annual, biennial and perennial weeds [2] [3]. Glyphosate is the most widely used herbicide in the world with potential to be tankmixed with various herbicides for effective weed management in many different crops [3]. Glyphosate can be tankmixed with saflufenacil and mesotrione and be applied preplant for effective burndown of emerged weeds in reduced or no-till cropping systems [5].

In other studies, saflufenacil has been shown to be an effective tool to control winter annual weeds such as blue mustard (Chorispora tenella Pallas), shepherd's purse (Capsella bursa-pastoris L.), henbit (Lamium amplexicaule L.), field pennycress (Thlaspi arvense L.), flixweed (Descurainia Sophia L.), and perennials such as dandelion (Taraxacum officinale Weber) and field bindweed (Convolvulus arvensis L.) [7]-[9]. Additionally, in other studies mesotrione applied POST at rates of 192 to $280 \mathrm{~g}_{\text {ai ha }}{ }^{-1}$ has been shown to provide up to $95 \%$ control of common ragweed and wild mustard in cereals [10]. In another study, mesotrione provided $80 \%$ or greater reduction in density and biomass of common lambsquarters and wild mustard and less than $80 \%$ reduction in density and biomass of common ragweed and wild buckwheat in spring seeded wheat, barley and oats [11].

There is potential for mesotrione and saflufenacil to be used with glyphosate as an enhanced burndown prior to seeding winter wheat as well as providing residual control of annual broadleaf weeds the following spring. Since glyphosate-resistant weeds have been documented in some areas of Ontario, growers will need herbicide options other than glyphosate for burndown in winter wheat. If there is adequate tolerance in winter wheat to mesotrione and saflufenacil applied prior to seeding in the autumn, it may eliminate the need for broadleaf herbicides in the spring.

There is limited information published on the efficacy of glyphosate plus mesotrione or glyphosate plus saflufenacil for the control of broadleaved weeds when applied preplant in the autumn under Ontario environmental conditions. Mesotrione and saflufenacil provide winter wheat growers with possible additional herbicide options for broadleaved weed control including acetolactate synthase, triazine and glyphosate-resistant biotypes.

The objective of this study was to evaluate the effect of glyphosate plus mesotrione and glyphosate plus saflufenacil at various rates for the control of broadleaf weeds and red clover establishment in winter wheat under Ontario environmental conditions. 


\section{Materials and Methods}

A total of 12 field trials (six experiments with mesotrione tankmixes and six experiments with saflufenacil tankmixes conducted side by side) were conducted at two locations (Huron Research Station, Exeter, Ontario and University of Guelph Ridgetown Campus, Ridgetown, Ontario) in the autumn of 2010, 2011 and 2012. The soil at Exeter was a Brookston clay loam (Orthic Humic Gleysol, mixed, mesic, and poorly drained) and the soil at Ridgetown was a Watford-Brady clay loam (Gleyed Brunisolic Grey to Brown Luvisol, mixed, mesic, and imperfectly drained).

The experimental design was a randomized complete block design with four replicates. Treatments are listed in Table 1 and Table 2 for mesotrione trials and Table 3 and Table 4 for saflufenacil trials. Plots were $2 \mathrm{~m}$

Table 1. Visual estimates of percent AMBEL and SINAR weed control 2 and 4 WAE and at the beginning of May and June the following year and winter wheat yield with preplant applications of glyphosate alone and in combination with mesotrione at different rates in winter wheat at Ridgetown and Exeter, ON (2011-2013). There was no significant rate effect for any evaluation ${ }^{\mathrm{a}}$.

\begin{tabular}{|c|c|c|c|c|c|c|c|c|}
\hline \multirow{4}{*}{ Treatment $^{\mathrm{b}}$} & \multirow{4}{*}{$\begin{array}{c}\text { Rate } \\
\text { g ai/ae ha }^{-1}\end{array}$} & \multicolumn{6}{|c|}{ Weed Control } & \multirow{4}{*}{$\begin{array}{l}\text { Yield } \\
\left(\mathrm{T} \cdot h \mathrm{a}^{-1}\right)\end{array}$} \\
\hline & & AMBEL & AMBEL & SINAR & SINAR & SINAR & SINAR & \\
\hline & & May & June & $2 \mathrm{WAE}$ & $4 \mathrm{WAE}$ & May & June & \\
\hline & & \multicolumn{6}{|c|}{ (\%) } & \\
\hline Glyphosate & 900 & 1 & 1 & 87 & 96 & 31 & 2 & 6.6 \\
\hline Glyphosate + Mesotrione & $900+12.5$ & 1 & 1 & 96 & 98 & 54 & 3 & 6.7 \\
\hline Glyphosate + Mesotrione & $900+25$ & 1 & 3 & 95 & 97 & 75 & 25 & 6.8 \\
\hline Glyphosate + Mesotrione & $900+50$ & 1 & 2 & 99 & 98 & 71 & 26 & 6.7 \\
\hline Glyphosate + Mesotrione & $900+75$ & 2 & 2 & 99 & 98 & 67 & 25 & 6.6 \\
\hline Glyphosate + Mesotrione & $900+100$ & 1 & 2 & 100 & 98 & 59 & 13 & 6.8 \\
\hline Glyphosate + Mesotrione & $900+150$ & 2 & 2 & 100 & 100 & 77 & 24 & 6.5 \\
\hline Glyphosate + Mesotrione & $900+200$ & 7 & 4 & 100 & 100 & 65 & 29 & 6.6 \\
\hline
\end{tabular}

${ }^{\mathrm{a}}$ Abbreviations: AMBEL, common ragweed; WAE, week after crop emergence; SINAR, wild mustard; ${ }^{\mathrm{b}}$ Agral 90 added at $0.2 \%$ v/v to all mesotrione treatments.

Table 2. Visual estimates of red clover establishment and dry weight taken mid-August after preplant applications of glyphosate alone and in combination with mesotrione at different rates in winter wheat at Ridgetown and Exeter, ON (2011-2013). Means not significantly different according to Fisher's Protected LSD at $\mathrm{P}<0.05^{\mathrm{a}}$.

\begin{tabular}{cccc}
\hline & Rate & Red clover & Red clover \\
\cline { 2 - 4 } Treatment & g ai/ae ha ${ }^{-1}$ & Est $(0-10)$ & Dry Weight (grams) \\
\hline Glyphosate & 900 & $9.3^{\mathrm{a}}$ & 53.5 \\
Glyphosate + Mesotrione & $900+12.5$ & $9.4^{\mathrm{a}}$ & 57.2 \\
Glyphosate + Mesotrione & $900+25$ & $9.1^{\mathrm{ab}}$ & 64.4 \\
Glyphosate + Mesotrione & $900+50$ & $9.1^{\mathrm{ab}}$ & 54.8 \\
Glyphosate + Mesotrione & $900+75$ & $8.8^{\mathrm{ab}}$ & 60.8 \\
Glyphosate + Mesotrione & $900+100$ & $8.9^{\mathrm{ab}}$ & 55.9 \\
Glyphosate + Mesotrione & $900+150$ & $8.0^{\mathrm{bc}}$ & 47.0 \\
Glyphosate + Mesotrione & $900+200$ & $7.3^{\mathrm{c}}$ & 41.2 \\
\hline
\end{tabular}

${ }^{\mathrm{a}}$ Abbreviations: Est, establishment; ${ }^{\mathrm{b}} \mathrm{Agral} 90$ added at $0.2 \% \mathrm{v} / \mathrm{v}$ to all mesotrione treatments. 
Table 3. Percent visual weed control of AMBEL, CHEAL and SINAR 2 and 4 WAE and at the beginning of May and June the following year and winter wheat moisture and yield with preplant applications of glyphosate alone and in combination with saflufenacil at different rates at Ridgetown and Exeter, ON (2011-2013). Means followed by the same letter within a column are not significantly different according to Fisher's Protected LSD at $\mathrm{P}<0.05^{\mathrm{a}}$.

\begin{tabular}{|c|c|c|c|c|c|c|c|c|c|c|c|}
\hline \multirow{4}{*}{ Treatment $^{\mathrm{b}}$} & \multirow{4}{*}{$\begin{array}{c}\text { Rate } \\
\text { g ai/ae ha }{ }^{-1}\end{array}$} & \multicolumn{8}{|c|}{ Weed Control } & \multirow{4}{*}{ Moisture } & \multirow{4}{*}{$\begin{array}{l}\text { Yield } \\
\text { T/ha }\end{array}$} \\
\hline & & AMBEL & AMBEL & CHEAL & CHEAL & SINAR & SINAR & SINAR & SINAR & & \\
\hline & & May & June & May & June & $2 \mathrm{WAE}$ & $4 \mathrm{WAE}$ & May & June & & \\
\hline & & \multicolumn{8}{|c|}{ (\%) } & & \\
\hline Glyphosate & 900 & $2 \mathrm{c}$ & $1 \mathrm{c}$ & 0 & 0 & $74 \mathrm{~b}$ & 74 & $9^{\mathrm{d}}$ & $0 \mathrm{~b}$ & 14.3 & 6.2 \\
\hline Glyphosate + Saflufenacil & $900+12.5$ & $2 \mathrm{c}$ & $3 c$ & 0 & 0 & $100 \mathrm{a}$ & 96 & $43^{c}$ & 8 a & 14.1 & 5.9 \\
\hline Glyphosate + Saflufenacil & $900+25$ & $4 \mathrm{c}$ & $1 \mathrm{c}$ & 1 & 0 & $100 \mathrm{a}$ & 98 & $61^{\mathrm{abc}}$ & $11 \mathrm{a}$ & 14.0 & 6.0 \\
\hline Glyphosate + Saflufenacil & $900+50$ & $14 \mathrm{~b}$ & $3 c$ & 2 & 0 & 100 a & 99 & $51^{\mathrm{bc}}$ & 16 a & 14.0 & 5.9 \\
\hline Glyphosate + Saflufenacil & $900+75$ & $25 \mathrm{ab}$ & 6 bc & 3 & 0 & $100 \mathrm{a}$ & 99 & $85^{\mathrm{ab}}$ & $12 \mathrm{a}$ & 14.2 & 6.1 \\
\hline Glyphosate + Saflufenacil & $900+100$ & $25 \mathrm{ab}$ & $11 \mathrm{ab}$ & 3 & 0 & $100 \mathrm{a}$ & 100 & $88^{\mathrm{a}}$ & $12 \mathrm{a}$ & 14.0 & 6.1 \\
\hline Glyphosate + Saflufenacil & $900+150$ & 29 a & $17 \mathrm{ab}$ & 4 & 2 & $100 \mathrm{a}$ & 100 & $77^{\mathrm{abc}}$ & $17 \mathrm{a}$ & 13.9 & 6.4 \\
\hline Glyphosate + Saflufenacil & $900+200$ & $30 \mathrm{a}$ & $18 \mathrm{a}$ & 4 & 5 & $100 \mathrm{a}$ & 100 & $72^{\mathrm{abc}}$ & 35 a & 13.9 & 6.2 \\
\hline
\end{tabular}

${ }^{a}$ Abbreviations: AMBEL, common ragweed; CHEAL, common lambsquarters; WAE, weeks after crop emergence; SINAR, wild mustard; ${ }^{\mathrm{b}}$ Merge added at $1 \mathrm{~L} \cdot \mathrm{ha}^{-1}$ to all saflufenacil treatments.

Table 4. Visual estimates of red clover establishment and dry weight taken mid-August after preplant applications of glyphosate alone and in combination with saflufenacil at different rates in winter wheat at Ridgetown and Exeter, ON (2011-2013). Means for both variables were not significantly different according to Fisher's Protected LSD at $\mathrm{P}<0.05^{\mathrm{a}}$.

\begin{tabular}{cccc}
\hline & Rate & Red clover & Red clover \\
\cline { 2 - 4 } Treatment & g ai/ae ha ${ }^{\mathrm{b}}$ & Est $(0-10)$ & Dry Weight $\left(\mathrm{g} \cdot \mathrm{m}^{-2}\right)$ \\
\hline Glyphosate & 900 & 9 & 61 \\
Glyphosate + Saflufenacil & $900+12.5$ & 9 & 70 \\
Glyphosate + Saflufenacil & $900+25$ & 9 & 59 \\
Glyphosate + Saflufenacil & $900+50$ & 9 & 56 \\
Glyphosate + Saflufenacil & $900+75$ & 9 & 72 \\
Glyphosate + Saflufenacil & $900+100$ & 8 & 65 \\
Glyphosate + Saflufenacil & $900+150$ & 9 & 62 \\
Glyphosate + Saflufenacil & $900+200$ & 9 & 70 \\
\hline
\end{tabular}

${ }^{\mathrm{a}}$ Abbreviations: Est, establishment; ${ }^{\mathrm{b}}$ Merge added at $1 \mathrm{~L} \cdot \mathrm{ha}{ }^{-1}$ to all saflufenacil treatment.

wide and $10 \mathrm{~m}$ long at Exeter and $2 \mathrm{~m}$ wide and $8 \mathrm{~m}$ long at Ridgetown. Pioneer "25R47", a commonly grown soft, red winter wheat cultivar in Ontario, was seeded in rows spaced $18 \mathrm{~cm}$ apart. At all locations, winter wheat was seeded $3 \mathrm{~cm}$ deep at a rate of $150 \mathrm{~kg} \cdot \mathrm{ha}^{-1}$ using a double disk planter in late September to early October. Red clover was broadcast at a rate of $11 \mathrm{~kg} \cdot \mathrm{ha}^{-1}$ in late winter (March to April) of the subsequent calendar year.

Herbicide applications were made with a $\mathrm{CO}_{2}$-pressurized backpack sprayer calibrated to deliver $200 \mathrm{l} \cdot \mathrm{ha}^{-1}$ of spray solution at a pressure of $240 \mathrm{kPa}$. The boom was $1.5 \mathrm{~m}$ long with four 8002 flat-fan nozzles (Teejet 8002 flat-fan nozzle tip; Spraying Systems Co., P. O. Box 7900, Wheaton, IL 60188) spaced 0.5 m apart. Herbicide applications were made 1 day before seeding.

Estimate of crop injury and weed control were evaluated on a scale of $0 \%$ to $100 \%$ at 2 and 4 weeks after 
emergence (WAE) in the autumn and on May 1 and June 1 of the following spring. A rating of 0 was defined as no visible injury/weed control and a rating of 100 was defined as total necrosis of crop/weed. Yield was measured at crop maturity by harvesting the middle $1.5 \mathrm{~m}$ of each plot with a plot combine. Winter wheat was harvested at both locations in late July to early August in 2011, 2012 and 2013. Yields were adjusted to 14.5\% moisture. Visual estimate of red clover establishment was rated on a scale of 0 (bare ground) to 10 (equivalent to the untreated check) on August 15 of each year. Red clover dry weight was determined on August 15 by cutting plants at the soil surface for $0.5 \mathrm{~m}^{2}$ per plot. Plants were dried at $60^{\circ} \mathrm{C}$ to constant moisture and then weighed.

All data were subjected to analysis of variance (ANOVA) and were combined over experiments and years and analyzed using the PROC MIXED procedure of SAS (The SAS System for Windows, Release 8.0e, SAS Institute Inc., P. O. Box 8000, Cary, NC 27512). Variances were partitioned into the fixed effects of herbicide treatment and into the random effects of locations, years, locations by years, blocks within years by locations, and their interactions with fixed effects (herbicide treatments). Significance of random effects was tested using a Z-test of the variance estimate and fixed effects were tested using F-tests. Error assumptions of the variance analyses (random, homogeneous, normal distribution of error) were confirmed using residual plots and the Shapiro-Wilk normality test. To meet the assumptions of normality, yield and clover establishment at August 15 were untransformed, AMBEL data in May and AMBEL data in June were log transformed; red clover dry weight was square root transformed; SINAR data at 2 and 4 WAE, SINAR data at May and June were arcsine square root transformed. Data were combined and analyzed over environments when possible (i.e. environment by timing by rate interactions were not significant). Means were separated using Fisher's protected LSD. Type I error was set at 0.05 for all statistical comparisons. Data compared on the transformed scale were converted back to the original scale for presentation of results.

\section{Results and Discussion}

\subsection{Glyphosate plus Mesotrione}

There was minimal injury ( $0 \%-2 \%)$ injury in winter wheat with glyphosate and glyphosate plus mesotrione at the evaluated rate 2 and 4 WAE in the autumn and on May 1 and June 1 of the following spring (data not shown).

The preplant applications of glyphosate $\left(900 \mathrm{~g} \mathrm{ae} \mathrm{ha}^{-1}\right.$ ) and tankmixes of glyphosate (900 $\mathrm{g}$ ae ha ${ }^{-1}$ ) plus mesotrione at 12.5, 25, 50, 75, 100, 150 and $200 \mathrm{~g}_{\text {ai ha }}{ }^{-1}$ provided poor residual control (1\% - 7\%) of common ragweed evaluated on the first of May and June of the following spring. The PP application of glyphosate and mesotrione controlled wild mustard $87 \%-100 \%$ at 2 and 4 WAE but provided only $31 \%-77 \%$ and $2 \%-29 \%$ control on May $1^{\text {st }}$ and June $1^{\text {st }}$ of the following spring, respectively (Table 1 ). There were no significant differences between treatments for controlling common ragweed and wild mustard in winter wheat. In other studies mesotrione controlled common ragweed at rates greater than $280 \mathrm{~g}$ a ha ${ }^{-1}$ in cereals [10]. Similarly, mesotrione had to be applied at 73 and $192 \mathrm{~g}$ ai ha ${ }^{-1}$ to provide 80 and $95 \%$ control of wild mustard in cereals, respectively [10]. Mesotrione has been shown to provide $80 \%$ or greater reduction in density and biomass of common lambsquarters and wild mustard and less than $80 \%$ reduction in density and biomass of common ragweed and wild buckwheat in spring seeded wheat, barley and oats [11].

Visual estimates of red clover establishment and dry weight taken on August 15 after preplant applications of glyphosate alone and in combination with mesotrione at different rates in winter wheat indicated no significant effect except with red clover establishment which was reduced with glyphosate plus mesotrione $13 \%$ (8.0 vs

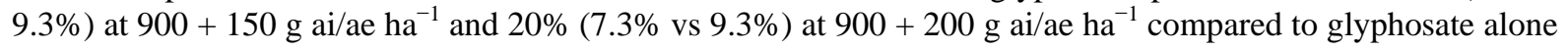
(Table 2).

The preplant application of glyphosate $\left(900 \mathrm{~g}_{\text {ae }} \mathrm{ha}^{-1}\right)$ plus mesotrione at 12.5, 25, 50, 75, 100, 150 or $200 \mathrm{~g}$ ai ha ${ }^{-1}$ did not have any effect on seed moisture content and yield of winter wheat compared to glyphosate alone applied at $900 \mathrm{~g}_{\mathrm{ge} \mathrm{ha}}{ }^{-1}$ (Table 1 ).

\subsection{Glyphosate plus Saflufenacil}

There was minimal injury (0-2\%) injury in winter wheat with glyphosate and glyphosate plus saflufenacil at the evaluated rates 2 and 4 WAE in the autumn and on May 1 and June 1 of the following spring (data not shown). The amount of injury seen with saflufenacil applied PP in the autumn is significantly lower than those reported 
with saflufenacil applied POST in other studies. Frihauf et al. [12] found that saflufenacil applied POST at 25 to $50 \mathrm{~g}$ a.i. $\mathrm{ha}^{-1}$ caused $27 \%$ - 38\% injury in winter wheat at 1 week after treatment (WAT). Sikkema et al. [13] found as much as $67 \%$ injury with saflufenacil applied POST at $50 \mathrm{~g}$ a.i. ha ${ }^{-1}$ three days after treatment in spring cereals.

The preplant applications of glyphosate $\left(900 \mathrm{~g}_{\text {ae }} \mathrm{ha}^{-1}\right.$ ) and tankmixes of glyphosate (900 $\mathrm{g}$ ae ha ${ }^{-1}$ ) plus saflufenacil at 12.5, 25, 50, 75, 100, 150 and $200 \mathrm{~g}_{\text {ai ha }}{ }^{-1}$ provided $1 \%-30 \%$ control of common ragweed and $0 \%-5 \%$ control of common lambsquarters evaluated on the first of May and June of the following spring. The PP application of glyphosate and saflufenacil controlled wild mustard $74 \%-100 \%$ at 2 and 4 WAE but provided $9 \%-88 \%$ and $0 \%-35 \%$ control on May $1^{\text {st }}$ and June $1^{\text {st }}$ of the following spring, respectively (Table 3 ). The control of common ragweed and wild mustard evaluated on the May 1 of the following spring was generally improved with the higher rates of saflufenacil (Table 3). In other studies, prosulfuron in combination with glyphosate provided $73 \%$ - 98\% control of common ragweed, less than $43 \%$ control of field bindweed, 39\% - 94\% control of wild buckwheat, $63 \%-98 \%$ control of wild mustard and $60 \%-85 \%$ control of perennial sowthisle [14].

Visual estimates of red clover establishment and dry weight taken on August 15 after preplant applications of glyphosate alone and in combination with saflufenacil at different rates in winter wheat indicated no significant differences between treatments evaluated (Table 4).

The preplant application of glyphosate $\left(900 \mathrm{~g}_{\text {ae }} \mathrm{ha}^{-1}\right.$ ) plus saflufenacil at 12.5, 25, 50, 75, 100, $150 \mathrm{or} 200 \mathrm{~g}$ ai ha ${ }^{-1}$ did not have any effect on seed moisture content and yield of winter wheat compared to glyphosate alone applied at $900 \mathrm{~g}_{\text {ae ha }}{ }^{-1}$ (Table 3). Winter wheat yield with saflufenacil applied PP in the autumn was significantly lower than those reported with saflufenacil applied POST in other studies. Knezevic et al. [15] reported up to $66 \%$ yield reduction with saflufenacil applied POST in the autumn in winter wheat.

\section{Conclusion}

Glyphosate (900 $\mathrm{g}_{\text {ae }} \mathrm{ha}^{-1}$ ) and tankmixes of glyphosate $\left(900 \mathrm{~g}_{\text {ae }} \mathrm{ha}^{-1}\right)$ plus mesotrione or saflufenacil at 12.5 , $25,50,75,100,150$ and $200 \mathrm{~g}_{\text {ai }} \mathrm{ha}^{-1}$ applied preplant did not result in any commercially significant visible injury in winter wheat evaluated in the autumn and on May 1 and June 1 of the following spring. The PP application of glyphosate alone or in combination with mesotrione or saflufenacil provided poor control of common ragweed and common lambsquarters of the following spring. The PP application of glyphosate in combination with mesotrione or saflufenacil especially at the higher rates provided good control of wild mustard at 2 and 4 WAE but the control was less than adequate the following spring. The preplant application of glyphosate plus mesotrione or saflufenacil did not have any effect on seed moisture content and yield of winter wheat compared to glyphosate alone. Red clover establishment was reduced with glyphosate plus mesotrione at the two highest rates but was not significantly affected with glyphosate plus saflufenacil compared to glyphosate alone. Based on these results, glyphosate $\left(900 \mathrm{~g}_{\mathrm{ae} \mathrm{ha}}{ }^{-1}\right.$ ) and tankmixes of glyphosate (900 $\mathrm{g}$ ae ha ${ }^{-1}$ ) plus mesotrione or saflufenacil at $12.5,25,50,75,100,150$ and $200 \mathrm{~g}_{\text {ai ha }}{ }^{-1}$ applied preplant in the autumn does not provide adequate residual control of common ragweed, common lambsquarters and wild mustard the following spring in winter wheat.

\section{Acknowledgements}

The authors would like to acknowledge Todd Cowan for his expertise and technical assistance in these studies. Funding for this project was provided in part by the Grain Farmers of Ontario (GFO) and the GF2 program of the Agricultural Adaptation Council.

\section{References}

[1] Anonymous (2013) Alberta Wheat Commission, Growth Innovation Results. http://www.albertawheat.com/about-wheat/canada/

[2] Ontario Ministry of Agriculture, Food and Rural Affairs (2014) Guide to Weed Control, Publication 75. Ontario Ministry of Agriculture, Food and Rural Affairs, Toronto, 425 p.

[3] Shaner, D.L. (2014) Herbicide Handbook. 10th Edition, Weed Science Society of America, Champaign, 513 p.

[4] Anonymous (2008) Kixor® Worldwide Technical Brochure. BASF Corporation, Research Triangle Park, 18 p. 
[5] Liebl, R.A., Walter, H., Bowe, S.J., Holt, T.J. and Westberg, D.E. (2008) BAS 800H: A New Herbicide for Preplant Burndown and Preemergence Dicot Weed Control. Weed Sci. Soc. Amer. Abstract, 48, 120.

[6] Moran, M.E. (2010) Preemergence and Postemergence Interactions of Saflufenacil in Corn (Zea mays L.). M.Sc. Thesis, University of Guelph, Guelp.

[7] Frihauf, J.C., Stahlman, P.W., Geier, P.W. and Peterson, D.E. (2010) Winter Annual Broadleaf Weeds and Winter Wheat Response to Postemergence Application of Two Saflufenacil Formulations. Weed Technology, 24, 416-424. http://dx.doi.org/10.1614/WT-D-09-00049.1

[8] Geier, P.W., Stahlman, P.W. and Charvat, L.D. (2009) Dose Responses of Five Broadleaf Weeds to Saflufenacil. Weed Technology, 23, 313-316. http://dx.doi.org/10.1614/WT-08-085.1

[9] Knezevic, S.Z., Datta, A., Scott, J. and Charvat, L.D. (2010) Tolerance of Winter Wheat (Triticum aestivum L.) to PreEmergence and Post-Emergence Application of Saflufenacil. Crop Protection, 29, 148-152.

[10] Martin, D.A., Miller, S.D. and Alley, H.P. (1989) Winter Wheat (Triticum aestivum L.) Response to Herbicides Applied at Three Growth Stages. Weed Technology, 3, 90-94.

[11] Soltani, N., Shropshire, C. and Sikkema, P.H. (2014) Weed Management in Spring Planted Cereals with Mesotrione. American Journal of Plant Sciences, 5, 153-157. http://dx.doi.org/10.4236/ajps.2014.51020

[12] Frihauf, J.C., Stahlman, P.W. and Geier, R.W. (2010) Winter Wheat and Weed Response to Postemergence Saflufenacil Alone and in Mixtures. Weed Technology, 24, 262-268. http://dx.doi.org/10.1614/WT-D-09-00020.1

[13] Sikkema, P.H., Shropshire, C. and Soltani, N. (2008) Tolerance of Spring Barley (Hordeum vulgare L.), Oats (Avena sativa L.) and Wheat (Triticum aestivum L.) to Saflufenacil. Crop Protection, 27, 1495-1497. http://dx.doi.org/10.1016/j.cropro.2008.07.009

[14] Soltani, N., Brown, L.R., Cowan, T. and Sikkema, P.H. (2014) Weed Management in Spring Seeded Barley, Oats, and Wheat with Prosulfuron. International Journal of Agronomy, 2014, Article ID: 950923. http://dx.doi.org/10.1155/2014/950923

[15] Knezevic, S.Z., Datta, A., Scott, J. and Charvat, L.D. (2010) Tolerance of Winter Wheat (Triticum aestivum L.) to Pre-Emergence and Post-Emergence Application of Saflufenacil. Crop Protection, 29, 148-152. http://dx.doi.org/10.1016/j.cropro.2009.08.017

\section{Abbreviations}

O.M. organic matter

PP pre-plant

POST post-emergence

PRE pre-emergence

WAE weeks after emergence 